\title{
BMJ Global Health Military coup during COVID-19 pandemic and health crisis in Myanmar
}

\author{
Su Myat Han, ${ }^{1,2}$ Kaung Suu Lwin (1) , ${ }^{3}$ Khin Thet Swe, ${ }^{4}$ Stuart Gilmour, ${ }^{5}$ \\ Shuhei Nomura (iD) 3,6
}

To cite: Han SM, Lwin KS, Swe KT, et al. Military coup during COVID-19 pandemic and health crisis in Myanmar. BMJ Global Health 2021;6:e005801. doi:10.1136/ bmjgh-2021-005801

Handling editor Seye Abimbola

SMH and KSL are joint first authors.

Received 23 March 2021 Accepted 23 March 2021

Check for updates

(c) Author(s) (or their employer(s)) 2021. Re-use permitted under CC BY-NC. No commercial re-use. See rights and permissions. Published by BMJ.

${ }^{1}$ Tropical Medicine and Global Health, Nagasaki University, Nagasaki, Japan

${ }^{2}$ Institute of Tropical Medicine, London School of Hygiene \&

Tropical Medicine, London, UK ${ }^{3}$ Department of Global Health Policy, The University of Tokyo, Bunkyo-ku, Japan

${ }^{4}$ Hitotsubashi Institute for Advanced Study, Hitotsubashi University, Kunitachi, Tokyo, Japan

${ }^{5}$ Graduate School of Public Health, St. Luke's International University, Chuo-ku, Tokyo, Japan

${ }^{6}$ Department of Health Policy and Management, Keio University, Tokyo, Japan

Correspondence to

Dr Kaung Suu Lwin;

kaungsuulwin@gmail.com
The military coup of February 1st 2021 is setting back Myanmar's transition to democracy and federalism and posing a threat to national health and human security. Many healthcare workers and other civil servants have stopped working, as part of a 'Civil Disobedience Movement' (CDM) as a peaceful, non-violent protest against the military coup. ${ }^{1}$

The global pandemic of COVID-19 has already disrupted Myanmar's existing fragile health systems and affected the country's many health services. As of February 2021, there were 140600 COVID-19 confirmed cases and 3100 deaths in Myanmar, one of the highest death rates in the region. ${ }^{2}$ The $\mathrm{CDM}$ has spread throughout the health workforce, resulting in closure of public hospitals, leading to a health system suddenly in crisis. ${ }^{3}$ Furthermore, the military takeover is leading to increased violence, further persecution of ethnic minorities and further difficulties for humanitarian access already hampered by the COVID-19 pandemic. ${ }^{34}$ While the global community has been fighting COVID-19, Myanmar citizens are also fighting for their freedom from oppression. ${ }^{3}$ This necessary response to protect their human rights risks increasing the spread of COVID-19 at a time when coordinated efforts to manage COVID-19 are hampered by political restrictions. ${ }^{3}$ Now it has been almost 2 months since the day of coup d'état, many peaceful protestors have been killed, injured or threatened, ${ }^{4}$ and the planned COVID-19 vaccination programme was disrupted by the coup d'état. ${ }^{3}$ Will Myanmar reach herd immunity through vaccination and win the democracy during this dual fight? Or will many lives be lost either by COVID-19 infection or by military's violence suppression and Myanmar fail to achieve democracy and surrender to the injustice of another military regime?

This military coup is an internal affair, but its impactgoes beyond the borders of Myanmar. The military coup threatens the health and human security of Myanmar and the wider region, due
Summary box

The world has witnessed Myanmar's ongoing military coup and detainment of President Win Myint and State Counsellor Aung San Suu Kyi.

- This coup is setting back Myanmar's transition to democracy and federalism and posing a threat to national health and human security.

- While global community has been fighting COVID-19, Myanmar citizens need to focus on fighting for their freedom from oppression.

- Protesting against the military coup is a civil right, however, the political instability caused disruption in management of COVID-19 which will impact international health security.

to the danger of a possible COVID-19 pandemic wave. We urge the global community to step in together with us, taking a strong stance to apply diplomatic pressure against the military coup, while maintaining their commitment to development aid in Myanmar at this critical time. Without help from the global community, the people of Myanmar risk losing the battle against COVID-19, and their long fight to emerge from military rule and oppression.

Twitter Stuart Gilmour @drStuartGilmour

Contributors KSL, SMH and KTS drafted the article. SN and GS revised it critically for important intellectual content

Funding The authors have not declared a specific grant for this research from any funding agency in the public, commercial or not-for-profit sectors.

\section{Competing interests None declared.}

Patient consent for publication Not required.

Provenance and peer review Not commissioned; internally peer reviewed.

Data availability statement There are no data in this work.

Open access This is an open access article distributed in accordance with the Creative Commons Attribution Non Commercial (CC BY-NC 4.0) license, which permits others to distribute, remix, adapt, build upon this work non-commercially, and license their derivative works on different terms, provided the original work is properly cited, appropriate credit is given, any changes made indicated, and the use is non-commercial. See: http://creativecommons.org/licenses/by-nc/4.0/. 


\section{ORCID iDs}

Kaung Suu Lwin http://orcid.org/0000-0002-0368-7018

Shuhei Nomura http://orcid.org/0000-0002-2963-7297

\section{REFERENCES}

1 Shepherd A. Myanmar medics resist military coup. BMJ 2021;372:n368
2 World Health Organization. WHO coronavirus disease (COVID-19) dashboard, 2020. Available: https://covid19.who.int/ [Accessed 9 Feb 2021].

3 Soe ZW, Oo MM, Wah KS, et al. Myanmar's health leaders stand against military rule. The Lancet 2021;397:875. doi:10.1016/S01406736(21)00457-8

4 Staff R. Myanmar protesters call for general strike against coup. Available: https://www.reuters.com/article/us-myanmar-politicsidUSKBN2AM032 [Accessed 22 Feb 2021]. 